\title{
Bridge plating for simple tibial fractures treated by minimally invasive plate osteosynthesis
}

\author{
[Estabilização em ponte de fraturas tibiais simples por osteossíntese minimamente \\ invasiva com placa]
}

\author{
B.M. Alcântara ${ }^{1}$, B.W. Minto ${ }^{2}$, G.G. Franco ${ }^{3}$, D.V.F. Lucena ${ }^{1}$, L.G.G.G. Dias ${ }^{2}$
}

\author{
${ }^{1}$ Aluno de pós-graduação - Faculdade de Ciências Agrárias e Veterinárias - Universidade Estadual \\ Paulista - Jaboticabal, SP \\ ${ }^{2}$ Faculdade de Ciências Agrárias e Veterinárias - Universidade Estadual Paulista - Jaboticabal, SP \\ ${ }^{3}$ Centro de Ciências e Engenharia Agronômica - Universidade Federal do Espírito Santo - Alegre, ES
}

\begin{abstract}
This study aimed to evaluate the effectiveness of bridge plating of simple tibial fractures in dogs by minimally invasive plate osteosynthesis (MIPO). Medical and radiographic records of twenty-nine dogs with simple tibial fractures that underwent bridge fixation by MIPO were retrospectively evaluated. The clinical outcome was classified considering the presence of lameness at the end of the treatment. The tibial mechanical joint angles were measured and compared with the values described in the literature. Additionally, fragment apposition and implant disposition were evaluated. Based on the modified Radiographic Union Scale for Tibial fractures, the moment of clinical union was determined. Clinically, at the end of treatment, only one patient presented lameness at a trot. While there was no significant difference between the bone alignment in the frontal plane values and the values described in the literature $(\mathrm{P}>0.05)$, the caudal proximal tibial angle was significantly higher $(\mathrm{P}=0.001)$. The median fragment apposition was considered acceptable. The average bridge plate ratio, plate working length, and plate screw density were $0.8,0.57$, and 0.48 , respectively. The median time to clinical union was 30 days. Bridge plating in simple tibial fractures resulted in fast healing and low complication rates.
\end{abstract}

Keywords: angular deformity, biological osteosynthesis, fracture healing, internal fracture fixation

\section{RESUMO}

Objetivou-se avaliar a efetividade da estabilização em ponte de fraturas tibiais simples em cães utilizandose a técnica de osteossíntese minimamente invasiva com placa (MIPO). Registros médicos e radiográficos de 29 cães com fraturas simples de tíbia, fixadas em ponte por meio da MIPO, foram retrospectivamente avaliados. $O$ resultado clínico foi classificado com base na deambulação ao final do tratamento. Os ângulos articulares mecânicos da tíbia foram aferidos e comparados aos valores descritos na literatura. Adicionalmente, foram avaliadas a aposição dos fragmentos e a disposição dos implantes. Por meio da escala modificada de união radiográfica para fraturas de tíbia, determinou-se o momento de união clínica. Clinicamente, ao final do tratamento, apenas um animal apresentou claudicação ao trote. Não houve diferença significativa entre o alinhamento ósseo no plano frontal quando comparado com dados da literatura $(P>0,05)$, enquanto, no plano sagital, o ângulo mecânico caudal proximal da tíbia foi significativamente maior $(P=0,001)$. A mediana para aposição dos fragmentos foi considerada aceitável. As médias para relação placa em ponte, comprimento de trabalho da placa e densidade de parafusos da placa foram, respectivamente, 0,8; 0,57 e 0,48. A mediana para união clínica foi de 30 dias. A estabilização em ponte de fraturas tibiais simples resultou em rápida consolidação óssea, com baixas taxas de complicação.

Palavras-chave: consolidação da fratura, desvio angular, fixação interna de fraturas, osteossíntese biológica

Recebido em 8 de dezembro de 2020

Aceito em 23 de março de 2021

E-mail: brealcantara@yahoo.com.br 


\section{INTRODUCTION}

The treatment of long bone fractures involves multifactorial planning, for which mechanical, biological, and clinical factors involved in bone repair should be recognized and considered to obtain good results (Roush, 2005). Regarding the mechanical point, balancing and controlling interfragmentary micromovements depends on a combination of the fixation technique and fracture classification. Biologically, minimal interference is expected in the fracture environment (Elliott et al., 2016). Excessive interfragmentary movement is potentially deleterious, especially in simple fractures, which are considered high strain when micromotion persists after reduction. In this case, loads of the same magnitude generate considerably greater relative deformities in fractures with smaller gaps (Macedo et al., 2018).

Conceptually, anatomical reconstruction with interfragmentary compression based on open reduction and internal fixation (ORIF) is recommended for high-strain fractures, to ensure load sharing between implants and bone; however, in the biological scope, disadvantages exist, due to the excessive manipulation of adjacent soft tissues and interference with periosteal vascularization and primordial fracture hematoma (Pozzi et al., 2012). Additionally, excess stiffness is often seen, which results in stress protection and leads to bone resorption and delayed repair (Augat and Ruden, 2018; Macedo et al., 2018).

Meanwhile, indirect reduction with bridge plating aims to re-establish the mechanical axis and bone length and promote secondary bone healing by relative stability. The mechanical microenvironment created by this approach is favorable for low-strain fracture treatment, where interfragmentary movement is not very harmful to the repair process. The great advantage of this method is the possibility of a minimally invasive application (Perren, 2002; Perren et al., 2015), and therefore, it is appropriately used in minimally invasive plate osteosynthesis (MIPO), where the preservation of the fracture environment is maximized, and bone healing is optimized (Pozzi et al., 2012).

Regardless of whether the established guidelines for the surgical management of long bone fractures are being followed, the results of scientific publications and/or practical clinical observations are unclear regarding the use of different guidelines. The applicability and efficacy of bridge plating by MIPO in the long bones of dogs and cats have been described (Guiot and Déjardin, 2011; Boero et al., 2012); however, there are no clinical veterinary studies that exclusively and objectively evaluate this fixation method in simple fractures, as an alternative to ORIF. Thus, this study aimed to investigate the treatment of simple (two pieces, reconstructable) tibial fractures in dogs through bridge fixation by MIPO. Our hypothesis is based on the fact that bridge plating of these fractures, performed in a minimally invasive manner, would result in early bone healing with low complication rates.

\section{MATERIAL AND METHODS}

All experimental procedures were reviewed and approved by the Ethics Committee on the Use of Animals of the institution (protocol n. 06866/19). The clinical records of twenty-nine dogs, which were admitted between November 2012 and March 2020 to "Governador Laudo Natel" Veterinary Hospital at Unesp Jaboticabal, with complete, simple (two pieces: transverse, oblique, or spiral), non-articular, and closed tibial fractures that underwent bridge plating using MIPO were retrieved. Dogs with incomplete radiographic follow-up evaluation or with history of diseases that could compromise bone healing were excluded from this study. Information retrieved included patient age, body weight and breed, the time between the trauma and surgical procedure, surgical complications, implant size, and patient clinical evaluation at the end of the treatment.

Under general inhalational anesthesia and after the preparation for aseptic surgery, the animal was positioned in the lateral recumbency position to expose the medial aspect of the affected tibia. Indirect fracture reduction was performed through manual distraction, verifying bone alignment by the positions of the knee and tarsal joints, without intraoperative imaging. Surgical approach to the tibia was performed for MIPO (Pozzi and Lewis, 2009). Through proximal and distal incisions, an epiperiosteal tunnel was created to insert a stainless-steel locking compression plate (LCP) (Focus Ortopedia Veterinária $\bigcirc$, Brazil). All plates were applied in a bridging fashion with two or three locking screws per segment. The plate contouring and plate and screw dimensions were 
planned according to each patient, including $1.5 \mathrm{~mm}, 2 \mathrm{~mm}, 2.7 \mathrm{~mm}, 3.5 \mathrm{~mm}$, and $4.5 \mathrm{~mm}$ dimensions. The fascial planes (proximal and distal) were closed in layers using monofilament absorbable sutures and the skin in a separate simple interrupted pattern with a monofilament nonabsorbable suture.

At the end of treatment, the clinical outcome was defined based on the degree of claudication of the affected limb: grade 0: no lameness at a walk or trot; grade 1: lameness apparent only at a trot; grade 2: lameness at a walk and trot, grade 3: nonweightbearing most or all of the time, as adapted from Scott and Witte (2011). Orthogonal radiographs of the tibia were taken preoperatively, immediately postoperatively, and at each scheduled recheck. Re-examination were recommended at 15, 30, 60, 90, and 120 days, or until clinical union. These periodic radiographs were analyzed by three orthopedic surgeons, observing postoperative alignment, fragment apposition, implant disposition, and bone healing. The postoperative frontal plane alignment was based on the measurement of the mechanical medial proximal and distal tibial angles (mMPTA and mMDTA), while sagittal plane alignment was assessed by measuring the mechanical cranial distal tibial angle (mCrDTA) and caudal proximal tibial angle (mCaPTA). The values obtained were compared to those described in the literature (Dismukes et al., 2007, 2008), based on the t-test $(\mathrm{P}<0.05)$.

Postoperative fragment apposition was measured from the relationship between the dispersion of the fragments (the longest distance between the two fragments), in the mediolateral and craniocaudal projections, and the diameter of the isthmus of the tibia measured in the craniocaudal projection. When this relationship referred to values lower than or equal to $50 \%$, apposition was considered good (score 0). Values between 50\% and $100 \%$ were considered acceptable (score 1) and values greater than $100 \%$, inadequate (score 2), as adapted from Guiot and Déjardin (2011). Additionally, the plate size and number of screws were recorded. The relationship between plate length and tibia length (bridge plate ratio), distance between the screws near the fracture line and plate size (plate working length), and the number of screws used in relation to the number of plate holes (plate screw density) were calculated.

Bone healing was evaluated using the modified Radiographic Union Scale for Tibial fractures (mRUST) (Litrenta et al., 2015), considering clinical union when there was a bone bridge on three of four bone cortices on two orthogonal radiographic views. As adapted from Filgueira $e t$ al. (2019), the following parameters were also evaluated over time, by scores: periosteal reaction, cortical and medullary re-establishment, bone callus volume, presence of bridging callus, and remodeling. The presence of associations between the time of clinical union and the bone maturity (logistic regression), bridge plate ratio, and plate working length (variance analysis ANOVA) variables was also evaluated.

Descriptive analyses were performed considering the mean and standard deviation (SD), for the quantitative variables, and the median and mean absolute deviation (MAD), for the qualitative variables. The bone healing scores were analyzed using linear mixed models. The sources of variation considered in these models were the moments of radiographic analysis, and the animals and evaluators were the random effects of the model. The model residues met assumptions of normality, according to the Cramér-von Mises test, and a 5\% significance level was adopted. All analyses were performed in Software R using the "lme4" package (R Core Team, 2020).

\section{RESULTS}

Twenty-nine dogs were included in this study (Table 1) and $55 \%$ of them were female. The mean \pm SD age at the time of trauma was $2.5 \pm 3.8$ years (range, two months to 15 years), median age was 9 months, and $66 \%$ of animals were considered immature, which means the presence of open physeal plates. The mean \pm SD body weight was $14.3 \pm 10.9 \mathrm{~kg}$ (range, $2.7 \mathrm{~kg}$ to $51 \mathrm{~kg}$ ). Approximately $45 \%$ of the animals were mixedbreed dogs. In $72 \%$ of cases, there was an associated fibula fracture. Most fractures were in the middle third of the tibial diaphysis (83\%), and $48.3 \%$ of the fractures were classified as spiral, $41.4 \%$ as oblique, and $10.3 \%$ as transverse. The time between the trauma and surgery ranged from at least one day to a maximum of 15 days ( $4.5 \pm$ 2.6 days). 
Table 1 . Summary data for 29 dogs with simple tibial fracture that had bridge plating by minimally invasive plate osteosynthesis

\begin{tabular}{|c|c|c|c|c|c|}
\hline Dogs & Breed & Age & BW (kg) & Fracture & Plate \\
\hline 1 & MBD & $5 y$ & 7.1 & $\mathrm{D}$, middle, spiral & 2mm, 9ho., $5 \mathrm{sc}$. \\
\hline 2 & MBD & $2 \mathrm{~m}$ & 3.8 & $\mathrm{D}$, middle, spiral & $2 \mathrm{~mm}, 9$ ho., $4 \mathrm{sc}$ \\
\hline 3 & Pinscher & $13 y$ & 2.7 & $\mathrm{D}$, proximal, oblique & 1,5mm, 10ho., $5 \mathrm{sc}$. \\
\hline 4 & Shih Tzu & $8 \mathrm{~m}$ & 6.6 & $\mathrm{D}$, middle, spiral & $2 \mathrm{~mm}, 8$ ho., $4 \mathrm{sc}$. \\
\hline 5 & MBD & $9 \mathrm{~m}$ & 7.9 & $\mathrm{D}$, middle, transverse & $2 \mathrm{~mm}, 10$ ho., $4 \mathrm{sc}$. \\
\hline 6 & MBD & $2 y$ & 17 & $\mathrm{D}$, middle, spiral & $2,7 \mathrm{~mm}, 8$ ho., $4 \mathrm{sc}$ \\
\hline 7 & MBD & $1 \mathrm{y} 6 \mathrm{~m}$ & 26 & $\mathrm{D}$, middle, spiral & $4,5 \mathrm{~mm}, 12 \mathrm{ho.}, 5 \mathrm{sc}$. \\
\hline 8 & Cocker Spaniel & $8 \mathrm{~m}$ & 10 & $\mathrm{D}$, middle, spiral & $2,7 \mathrm{~mm}, 8$ ho., $5 \mathrm{sc}$ \\
\hline 9 & MBD & $5 \mathrm{~m}$ & 7 & $\mathrm{D}$, middle, oblique & $2,7 \mathrm{~mm}, 7$ ho., $4 \mathrm{sc}$ \\
\hline 10 & Bull Terrier & $1 y$ & 14 & $\mathrm{D}$, middle, oblique & $2 \mathrm{~mm}, 11$ ho., $5 \mathrm{sc}$ \\
\hline 11 & MBD & $7 \mathrm{~m}$ & 10 & $\mathrm{D}$, middle, spiral & $2,7 \mathrm{~mm}, 7$ ho., $4 \mathrm{sc}$ \\
\hline 12 & Labrador Retr. & $7 \mathrm{~m}$ & 30 & $\mathrm{D}$, middle, oblique & $3,5 \mathrm{~mm}, 11 \mathrm{ho.}, 6 \mathrm{sc}$ \\
\hline 13 & MBD & $7 \mathrm{~m}$ & 6.3 & D., middle, oblique & $2 \mathrm{~mm}, 10$ ho., $4 \mathrm{sc}$ \\
\hline 14 & Brazilian Mastiff & $5 y$ & 51 & $\mathrm{D}$, middle, oblique & $4,5 \mathrm{~mm}, 14$ ho., $6 \mathrm{sc}$. \\
\hline 15 & Dobermann & $3 \mathrm{~m}$ & 5.6 & $\mathrm{D}$, middle, transverse & $2 \mathrm{~mm}, 8$ ho., $4 \mathrm{sc}$. \\
\hline 16 & Border Collie & $8 \mathrm{~m}$ & 25 & $\mathrm{D}$, middle, spiral & $3,5 \mathrm{~mm}, 10$ ho., $4 \mathrm{sc}$. \\
\hline 17 & MBD & $7 \mathrm{~m}$ & 7.1 & $\mathrm{D}$, middle, oblique & $2 \mathrm{~mm}, 9$ ho., $4 \mathrm{sc}$. \\
\hline 18 & Poodle & $4 \mathrm{~m}$ & 3 & $\mathrm{D}$, middle, oblique & $2 \mathrm{~mm}, 10 \mathrm{ho.} .5 \mathrm{sc}$ \\
\hline 19 & Lhasa Apso & $1 \mathrm{y}$ & 10 & $\mathrm{D}$, middle, spiral & $2,7 \mathrm{~mm}, 6$ ho., $4 \mathrm{sc}$ \\
\hline 20 & Labrador & $8 \mathrm{~m}$ & 20 & $\mathrm{D}$, middle, spiral & $3,5 \mathrm{~mm}, 11 \mathrm{ho.}, 5 \mathrm{sc}$. \\
\hline 21 & MBD & $3 y$ & 24.2 & $\mathrm{D}$, distal, oblique & $3,5 \mathrm{~mm}, 11$ ho., $4 \mathrm{sc}$. \\
\hline 22 & Am. Staf. Terrier & $11 \mathrm{~m}$ & 27 & $\mathrm{D}$, proximal, oblique & $3,5 \mathrm{~mm}, 10$ ho., $4 \mathrm{sc}$ \\
\hline 23 & MBD & $9 m$ & 20.5 & $\mathrm{D}$, middle, spiral & $3,5 \mathrm{~mm}, 11$ ho., $4 \mathrm{sc}$ \\
\hline 24 & Pinscher & $10 y$ & 5.5 & $\mathrm{D}$, distal, spiral & $2 \mathrm{~mm}, 8$ ho., $5 \mathrm{sc}$ \\
\hline 25 & Aust. Cattle Dog & $4 \mathrm{~m}$ & 8 & $\mathrm{D}$, middle, oblique & $2,7 \mathrm{~mm}, 9$ ho., $4 \mathrm{sc}$ \\
\hline 26 & Rottweiler & $1 \mathrm{y}$ & 25.8 & $\mathrm{D}$, middle, oblique & $2,7 \mathrm{~mm}, 12 \mathrm{ho.}, 5 \mathrm{sc}$. \\
\hline 27 & MBD & $15 y$ & 13 & M, distal, spiral & $2,7 \mathrm{~mm}, 12$ ho., $5 \mathrm{sc}$ \\
\hline 28 & MBD & $5 y$ & 5.5 & $\mathrm{D}$, middle, transverse & $2 \mathrm{~mm}, 9$ ho., $6 \mathrm{sc}$ \\
\hline 29 & British Bulldog & $9 \mathrm{~m}$ & 16 & $\mathrm{D}$, middle, spiral & $2,7 \mathrm{~mm}, 9$ ho., $4 \mathrm{sc}$ \\
\hline
\end{tabular}

BW, body weight; Am. Staf., American Staffordshire; Aust., Australian; MBD, mixed breed dog; Retr., Retriever; m. months; y., years; D., diaphyseal; M., metaphyseal; ho., plate holes; sc., screws.

At the end of treatment, only one patient presented lameness at a trot, however it was controlled with anti-inflammatory; in the other animals, no lameness was observed at a walk or trot. There was one complication in which the surgery had to be reviewed due to the presence of a screw on the articular surface of the tibial plateau, observed on immediate postoperative radiography. Two cases presented proximal screw pull-out; however, surgical revision was not necessary, and the implants were removed at the end of the bone repair. The measured tibial mechanical joint angles (Figure 1) were compared to the values described in the literature (Table 2) (Dismukes et al., 2007, 2008), with statistical difference $(\mathrm{P}=0.001)$ for mCaPTA, which was higher. The median score of fragment apposition (Figure 2) was 1 (acceptable) (MAD = 1.48). Inadequate apposition was observed in five animals but all of them presented bone healing in the observed period, followed by bone remodeling.

Table 2. Mean and standard deviation of postoperative tibial mechanical joint angles compared with the values described in the literature, from the t-test, and p-values

\begin{tabular}{lccc}
\hline \multicolumn{1}{c}{ Variable } & Mean & SD & P-value \\
\hline mMPTA & 94.08 & 5.12 & 0.201 \\
mMDTA & 94.76 & 4.31 & 0.353 \\
mCrDTA & 85.60 & 6.52 & 0.070 \\
mCaPTA & 70.26 & 5.56 & 0.001 \\
\hline
\end{tabular}

mMPTA, mechanical medial proximal tibial angle; mmDTA, mechanical medial distal tibial angle; mCrDTA, mechanical cranial distal tibial angle; mCaPTA, mechanical caudal proximal tibial angle; SD, standard deviation. 


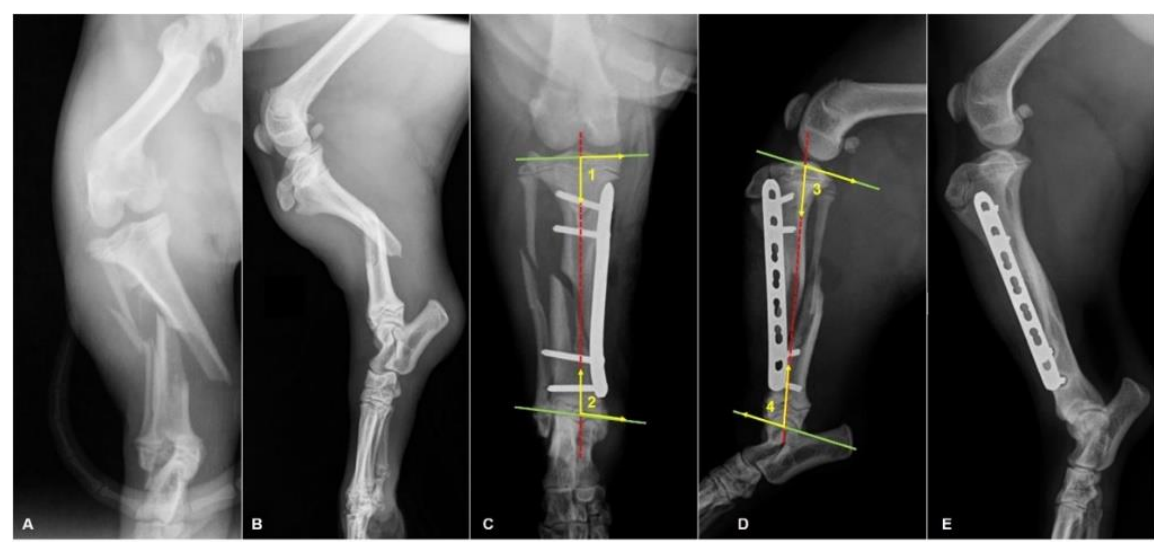

Figure 1. Preoperative craniocaudal (A) and mediolateral (B) radiographs of a middle third diaphysis spiral fracture in an eight-month-old, $6.6 \mathrm{~kg}$ Shih Tzu. Evaluation of postoperative alignment in frontal (C) and sagittal (D) planes: mechanical medial proximal (1) and distal (2) tibial angle, mechanical caudal proximal (3) and cranial distal (4) tibial angle. Inadequate apposition (score 2) in mediolateral projection. Bone remodeling process at 90 days $(\mathrm{E})$.

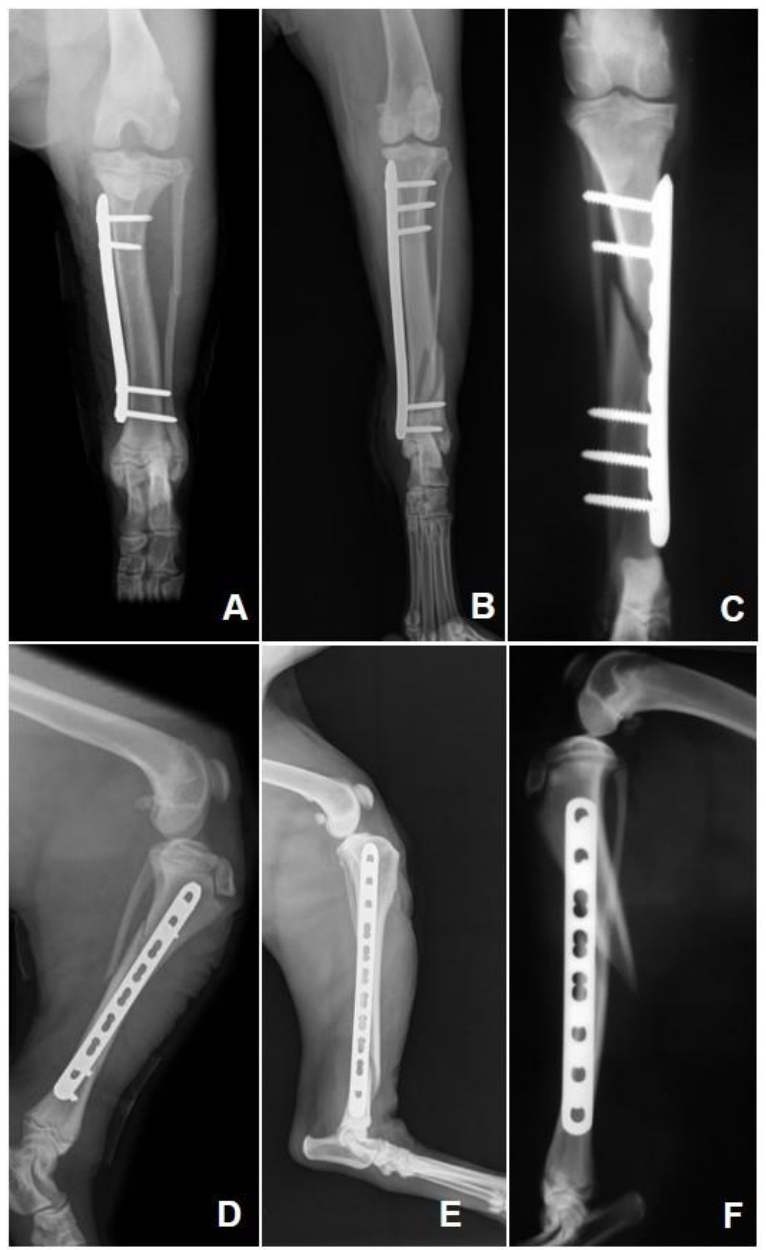

Figure 2. Immediate postoperative craniocaudal and mediolateral radiographs showing three cases with different postoperative fragment apposition classification. A and D: good apposition (score 0), B and E: acceptable apposition (score 1); C and F: inadequate apposition (score 2). 


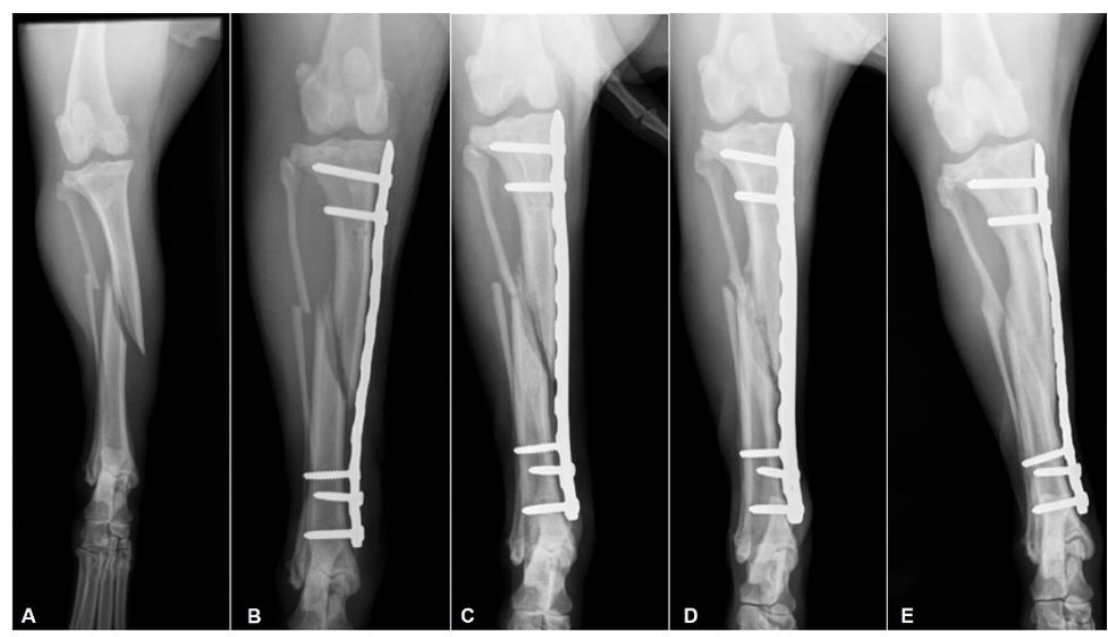

Figure 3. Radiographic follow-up of bridge fixation of a middle third diaphysis spiral fracture in a oneyear-old, 14kg Bull Terrier. A: Preoperative. B: Immediate postoperative period. C: 15 days, presence of periosteal reaction, with visible fracture line. D: 30 days, formation of lateral bridging callus. E: 60 days, cortical reestablishment and bone callus remodeling.

All cases were treated with a stainless-steel locking plate (LCP) in the bridge function. The mean \pm SD of the bridge plate ratio was $0.8 \pm 0.09$, while the plate working length was $0.57 \pm 0.08$, and the plate screw density was $0.48 \pm 0.09$. Regarding bone healing (Figure 3), day 30 was the median for clinical union (minimum 15 and maximum 90 days, MAD $=22.24$ ), based on mRUST. The time did not influence the periosteal reaction and bone callus volume parameters, and a score of 2 (discrete) was their median at all of the evaluation time points.

The presence of bridging callus had a maximum score, as the median, at day 30 , while cortical and medullary re-establishment occurred at day 60, when bone remodeling was also more remarkable. Clinical union was statistically associated with the patients' bone maturity $(\mathrm{P}=0.001)$ and plate working length $(\mathrm{P}=0.001)$, it was earlier in younger patients (with open physeal plates) and in cases with longer plate working length. There was no significant association between clinical union and the bridge plate ratio $(\mathrm{P}=0.11)$.

\section{DISCUSSION}

Two pieces fractures are potentially high-strain fractures, since they have long lever arm distance and, consequently, are mechanically more sensitive to relative movement in the fracture focus. Considering that point, conceptually, relative stabilization of high-strain fractures is not recommended (Perren et al., 2015; Macedo et al., 2018). However, based on our results, bridge plating of non-articular simple tibial fractures by MIPO in dogs was satisfactory, supporting the initial hypothesis of the study. In general, our favorable clinical and radiographic results are justified by the balance achieved between the mechanical and biological environments, which allowed for the formation of fibrous/cartilaginous callus fast enough to increase construction stiffness and neutralize the expected excess movement in high-strain fractures (Perren, 2014; Elliott et al., 2016), which is potentially harmful to bone healing (Macedo et al., 2018). A study that evaluated bridge fixation of tibial fractures in dogs, including comminuted and simple fractures, also described early clinical union in animals subjected to a minimally invasive approach (Boero et al., 2012).

The secondary bone repair process, observed in spontaneous healing or under flexible fixation, progresses due to increased tissue stiffness throughout the steps and load sharing between the implant and new tissue. Initially, the mechanical strain is higher but clinically, this value is reduced due to initial bone resorption and the onset of granulation tissue formation in some areas of the fracture (Perren, 2014; Perren et al., 2015; Elliott et al., 2016). Thus, the clinical strain is favored by both the appropriate initial fracture stability and 
early tissue formation, which is optimized in preserved biological environments.

Excessive soft tissue trauma can compromise bone callus formation; thus, the biological approach, without interference at the fracture focus and preserving the periosteum and its vascularization, as well as the primordial hematoma, which are sources of osteoprogenitor cells, cytokines, and growth factors, can be considered one of the main factors responsible for the success of the procedure (Wang et al., 2017; Walters et al., 2018). Regarding the mechanical environment, among the factors that contributed to sufficient stability of the fracture focus, adequate fragment apposition, which was considered good or acceptable in $82 \%$ of patients, stands out.

The fact that most fractures in our study were spiral or oblique and the time between the trauma and surgery was relatively short was favorable to indirect reduction. A recent study emphasized that an excessive distance between bone fragments can increase the rates of bone non-union, and good apposition is more important than bridge span length (Kiyono et al., 2019). Although fragment apposition was mostly satisfactory, anatomical reconstruction was not performed, remaining a gap, even if minimal, between bone fragments. This point should also be considered since if there were no gap, the strain would be higher, which would probably require more rigidity.

Likewise, a correct application of plates and screws is also an essential mechanical factor for obtaining good results (Niemeyer and Sudkamp, 2006). The plate working length is very important in the control of interfragmentary motion. When there is a fracture gap, large working length results in greater plate stress, but clinically, such stress reduces faster due to the early callus formation, because load bearing system become a load sharing system between implants and bone callus (MacLeod and Pankaj, 2018), justifying why in this study, despite the large working length, with a low density of screws, there was no fatigue failure. The elasticity increase was balanced, in turn, by the use of long plates, enhancing construction stability (Stoffel et al., 2003).

There was an association between plate working length and clinical union, where animals that presented an early clinical union (15 days) had a higher plate working length, which means that, even in simple fractures, the relative movement did not compromise secondary bone repair, indicating once again that the clinical strain was within the limits supported by the granulation tissue in the initial phase. If there was excessive instability in the fracture focus, it would prevent the formation of bone callus, even with adequate blood supply (Kiyono et al., 2019). Faster bone healing due to greater fixation flexibility can also be related to the evidence of a relationship between controlled cyclic movement and increased expression of bone morphogenetic proteins, which are inducers of osteogenic differentiation (Schreivogel et al., 2019).

In addition to the issues related to mechanical and biological factors discussed previously, we must better understand the real role of the locking plate in stabilizing fractures. It is known that, through fixed angle stability, LCPs provide a lower risk of reduction loss and greater micromotion control, when compared to dynamic compression plates (DCPs) (Cronier et al., 2010). Considering that high-strain fractures would respond better in more rigid environments (Perren, 2002), we believe that LCPs have promoted, to some degree, more stability than would be expected for bridge construction with a DCP plate, potentially favoring bone healing. Further studies should be conducted to better clarify the locking implant mechanisms, for micromotion control, especially in clinical scenarios (Gardner et al., 2005; Xue et al., 2016).

Angular deviations or an inadequate positioning of implants are limitations of indirect reduction by MIPO, even in the tibia, where the technique is favored by the low muscle coverage (Robinson $e t$ $a l ., 2019)$. In the cases analyzed, an increase of mCaPTA in relation to the values described in the literature indicated a tendency towards recurvatum deviations without, however, clinical repercussions during the observation period. The fact that the fractures were simple may have increased the chances of angular deviation since transverse fractures are especially prone to angular deformity when closed reduced and conservatively treated (Sarmiento et al., 2000). Intraoperative imaging or preoperative plate contouring could have facilitated a correct bone alignment (Guiot and Déjardin, 2011; Boero et al., 2012; Cabassu, 2019). 
The study limitations include the fact that it was a retrospective clinical study without weight, breed, and age standardization. Two-thirds of the patients were skeletally immature, which may have overestimated the positive results obtained since young animals consolidate more quickly and present good responses to elastic fixation (Cabassu, 2001; Guiot and Déjardin, 2011). This is confirmed by the existence of an association between clinical union and bone maturity, where younger dogs have earlier bone healing, as demonstrated in this study. Furthermore, the analysis of the tibial mechanical angles could have been more reliable if compared to the animal contralateral limb because, in chondrodystrophic breeds, for example, angular deviations are common, which would not necessarily have been caused by MIPO.

Choosing fixation methods based only on the fracture configuration can negatively impact bone healing. Conjunction between mechanical strain and the biological environment refers to the concept of clinical strain, and the balance between these factors is crucial, especially when the initial conditions are not biologically favorable, as in poorly vascularized areas. Thus, bridge fixation, as a mechanical alternative to ORIF, adds treatment options to the field of veterinary orthopedics.

\section{CONCLUSIONS}

Considering the early bone healing and low complication rates observed, bridge fixation can be applied in simple tibial fractures. Biological osteosynthesis might have contributed to our thriving results.

\section{ACKNOWLEDGEMENTS}

This study was financed in part by the Coordenação de Aperfeiçoamento de Pessoal de Nível Superior - Brasil (CAPES) - Finance Code 001.

\section{REFERENCES}

AUGAT, P.; RUDEN, C. Evolution of fracture treatment with bone plates. Injury, v.49, p.2-7, 2018.
BOERO, B.A.; PEIRONE, B.; WINTER, M.D. et al. Retrospective comparison between minimally invasive plate osteosynthesis and open plating for tibial fractures in dogs. Vet. Comp. Orthop. Traumatol., v.25, p.410-417, 2012.

CABASSU, J. Minimally invasive plate osteosynthesis using fracture reduction under the plate without intraoperative fluoroscopy to stabilize diaphyseal fractures of the tibia and femur in $\operatorname{dogs}$ and cats. Vet. Comp. Orthop. Traumatol., v.32, p.475-482, 2019.

CABASSU, J.P. Elastic plate osteosynthesis of femoral shaft fractures in young dogs. Vet. Comp. Orthop. Traumatol., v.14, p.40-45, 2001.

CRONIER, P.; PIETU, G.; DUJARDIN, C. et al. The concept of locking plates. Orthop. Traumatol. Surg. Res., v.96, p.17-36, 2010.

DISMUKES, D.I.; TOMLINSON, J.L.; FOX, D.B. et al. Radiographic measurement of the proximal and distal mechanical joint angles in the canine tibia. Vet. Surg., v.36, p.699-704, 2007.

DISMUKES, D.I.; TOMLINSON, J.L.; FOX, D.B. et al. Radiographic measurement of canine tibial angles in the sagittal plane. Vet. Surg., v.37, p.300-305, 2008.

ELLIOTT, D.S.; NEWMAN, K.J.H.; FORWARD, D.P. et al. A unified theory of bone healing and nonunion. Bone Joint J., v.98, p.884891, 2016.

FILGUEIRA, F.G.F.; MINTO, B.W.; CHUNG, D.G. et al. Platelet-rich plasma, bone marrow and chitosan in minimally invasive plate osteosynthesis of canine tibia fractures - a randomized study. Vet. Med., v.64, p.309-316, 2019.

GARDNER, M.J.; BROPHY, R.H.; CAMPBELL, D. et al. The mechanical behavior of locking compression plates compared with dynamic compression plates in a cadaver radius model. J. Orthop. Trauma, v.19, p.597-603, 2005.

GUIOT, L.P.; DÉJARDIN, L.M. Prospective evaluation of minimally invasive plate osteosynthesis in 36 nonarticular tibial fractures in dogs and cats. Vet. Surg., v.40, p.171-182, 2011. 
KIYONO, M.; NODA, T.; NAGANO, H. et al. Clinical outcomes of treatment with locking compression plates for distal femoral fractures in a retrospective cohort. J. Orthop. Surg. Res., v.14, p.1-9, 2019.

LITRENTA, J.; TORNETTA, P.; MEHTA, S. et al. Determination of radiographic healing: an assessment of consistency using RUST and modified RUST in metadiaphyseal fractures. $J$. Orthop. Trauma, v.29, p.516-520, 2015.

MACEDO, A.S.; MARINHO, P.V.T.; DAL-BÓ, I.S. et al. Physics behind the implants used for high strain fractures: literature review. Braz. J. Vet. Res. Anim. Sci., v.55, p.1-8, 2018.

MACLEOD, A.R.; PANKAJ, P. Pre-operative planning for fracture fixation using locking plates: device configuration and other considerations. Injury, v.49, p.12-18, 2018.

NIEMEYER, P.; SUDKAMP, N.P. Principles and clinical application of the Locking Compression Plate (LCP). Acta Chir. Orthop. Traumatol. Cech., v.73, p.221-228, 2006.

PERREN, S.M. Evolution of the internal fixation of long bone fractures. J. Bone Joint Surg., v.84, p.1093-1110, 2002.

PERREN, S.M. Fracture healing: fracture healing understood as the result of a fascinating cascade of physical and biological interactions. Part I. An attempt to integrate observations from 30 years AO research, Davos. Acta Chir. Orthop. Traumatol. Cech., v.81, p.355-364, 2014.

PERREN, S.M.; FERNANDEZ, A.; REGAZZONI, P. Understanding fracture healing biomechanics based on the "strain" concept and its clinical applications. Acta Chir. Orthop. Traumatol. Cech., v.82, p.253-260, 2015.

POZZI, A.; LEWIS, D.D. Surgical approaches for minimally invasive plate osteosynthesis in dogs. Vet. Comp. Orthop. Traumatol., v.22, p.316-320, 2009.

POZZI, A.; RISSELADA, M.; WINTER, M.D. Assessment of fracture healing after minimally invasive plate osteosynthesis or open reduction and internal fixation of coexisting radius and ulna fractures in dogs via ultrasonography and radiography. J. Am. Vet. Med. Assoc., v.241, p.744-753, 2012.
R Core Team. R: A language and environment for statistical computing. R Foundation for Statistical Computing, Vienna, Austria, 2020.

ROBINSON, W.P.; KNOWLES, T.G.; BARTHELEMY, N.P.; PARSONS, K.J. Perceptions of minimally invasive osteosynthesis: a 2018 survey of orthopedic surgeons. Vet. Surg., v.49, p.163-170, 2019.

ROUSH, J.K. Management of fractures in small animals. Vet. Clin. North Am. Small Anim. Pract., v.35, p.1137-1154, 2005.

SARMIENTO, A.; ZAGORSKI, J.B.; ZYCH, G.A. et al. Functional bracing for the treatment of fractures of the humeral diaphysis. J. Bone Joint Surg., v.82, p.478-486, 2000.

SCHREIVOGEL, S.; KUCHIBHOTLA, V.; KNAUS, P. et al. Load-induced osteogenic differentiation of mesenchymal stromal cells is caused by mechano-regulated autocrine signaling. J. Tissue Eng. Regen. Med., v.13, p.1992-2008, 2019.

SCOTT, H.; WITTE, P. Investigation of lameness in dogs. Forelimb. Practice, v.33, p.20-27, 2011.

STOFFEL, K.; DIETER, U.; STACHOWIAK, G. et al. Biomechanical testing of the LCP - how can stability in locked internal fixators be controlled? Injury, v.34, p.11-19, 2003.

WALTERS, G.; POUNTOS, I.; GIANNOUDIS, P.V. The cytokines and micro-environment of fracture haematoma: current evidence. J. Tissue Eng. Regen. Med., v.12, p.1662-1677, 2018.

WANG, T.; ZHANG, X.; BIKLE, D.D. Osteogenic differentiation of periosteal cells during fracture healing. J. Cell. Physiol., v.232, p.913-921, 2017.

XUE, Z.; XU, H.; DING, H. et al. Comparison of the effect on bone healing process of different implants used in minimally invasive plate osteosynthesis: limited contact dynamic compression plate versus locking compression plate. Sci. Rep., v.6, p.1-9, 2016. 